\title{
How Entrepreneurs Utilize Accelerators: A Demographic Factor Analysis in Turkey using Regression
}

\author{
Ceren Cubukcu ${ }^{1}$ \\ Computer Engineering Department \\ Engineering and Natural Sciences Faculty \\ Maltepe University, Istanbul, Turkey
}

\author{
Sevinc Gulsecen ${ }^{2}$ \\ Informatics Department \\ Istanbul University \\ Istanbul, Turkey
}

\begin{abstract}
This study examines entrepreneurs participating into eight accelerator programs located in Istanbul, Turkey. Business accelerators are a new kind of incubation program built in particular to help technology entrepreneurs and assist them reach to the next level. In total eight accelerator programs are researched in this study. A survey is developed for this study and applied to entrepreneurs attending these eight accelerator programs. In this survey, the effectiveness of these programs are measured according to the demographics of entrepreneurs. The aim of this research is to analyze how entrepreneurs use the services given by the accelerator program. In relation to entrepreneurs' age, gender, work experience, educational status and family background, several hypotheses have been identified for assessing the value of supports given in these accelerator programs. The data of this research have been examined via SPSS using Mann-Whitney and Kruskal-Wallis methods. According to the results of these tests, a regression model called Generalized Linear Mixed Model (GLMM) has been developed. This study adds to the literature by examining accelerator supports and facilities so that accelerators can set apart their programs in line with the requests of the entrepreneurs.
\end{abstract}

\section{Keywords-Accelerators; e-business; startups; regression}

\section{INTRODUCTION}

The development of internet started a new era for entrepreneurs especially for the ones in the technology field. Cloud technology and open source software have made it possible for entrepreneurs to develop a new business with less capital. Therefore, the expenses of founding a new technology business dropped significantly compared to the initial phases of internet and it is very easy to found an internet business [1]. However, in the 90s, the expenses of founding a new internet venture was high and involved more risks [2], [3]. For this reason, business incubators were established to help entrepreneurs and lower their risks. Incubators connected technology, talent, know-how and capital together in order to expedite the commercialization of technology [4]. They mainly provided office space and administrative assistance to innovative companies and also, gathered them together under the same roof for interaction [4]- [6]. Nonetheless, incubators lack an exit policy which caused problems for investors [7]. Therefore, in mid 2000s, a new a new kind of program called "accelerator" was born to support new businesses in technology sector which are also called startups.
Accelerators accelerate new businesses especially startups by becoming a bridge between them and the broader entrepreneurial environment [8] and offer them specific services for a certain extent, usually up to 6 months [9]. Among these services are office space, mentoring, training, networking, meeting with investors, advertising and access to different financing options [8], [10]- [14]. Startups use an open application system online to apply to these programs and go through a selection process to be accepted. Accelerators also help startups find seed/early-stage funding opportunities from investors. This is one of the major differences between an accelerator and an incubator. The incubators only provide tools, space and mentoring for startups [15] whereas an accelerator help the startups overcome the liability of newness and attract investors [16].

A predefined and firm description of an accelerator, plainly explaining the accelerator model from other incubation models is needed to choose the right programs for this study. Therefore, Miller and Bound's [12] definition of accelerators is used since it is widely accepted by many scholars [1], [10], [17], [18]. Accelerators have six main characteristics according to Miller and Bound [12]. These are; an application process open to all, time limited support, cohorts or classes of startups, seed investment in exchange for equity, a focus on small teams rather than individuals and finally, a graduation with a demo day [1], [17]. This study chooses to analyze accelerator programs located in Turkey due to Turkey is an emerging country according to Morgan Stanley Capital International emerging market index [19] and it is geographically considered as a bridge between Europe and Asia. Also, it has a population of 83 million according to World Population Review making it among the 20 largest countries of the world [20] and this population has very high internet and mobile phone penetration rates. According to Statista, there are 56 million internet users and 77.8 billion mobile phone users [21], [22]. All of these factors make Turkey a desired location for technology entrepreneurs. 28 accelerator programs exist in Turkey as of April 2018 and only 10 of these have the features of an accelerator program. All of these 10 programs are located in Istanbul. However, 8 of these programs agreed to participate on the research out of the 10, and this research implements a study on the entrepreneurs who have been through or are currently present in these eight accelerators. These are Starter's Hub, Pilot, ITU 
Seed, Kworks, SuCool, Albaraka Garaj, IOT Telco Labs and Lonca.

The aim of this research is to perform a statistical analysis on entrepreneurs in the eight accelerator programs stated above. More and more accelerator programs are opening up every year around the world and although it is known that success stories have emerged from accelerators, it has not been researched before thoroughly how effective their supports are for entrepreneurs. It will be analyzed how entrepreneurs use the services given by the accelerator program. By means of this research, accelerators will be able to differentiate their programs and the supports they provide according to entrepreneurs' needs and will be able to deliver them more beneficial programs. If the accelerator programs know which entrepreneurs need more support, they can direct them and contribute to their development in order to help startups grow more. In this way, entrepreneurs can grow their companies and increase their chances of success. This enlarges the entrepreneurship ecosystem and makes a positive contribution to a country's economy and employment rates.

Literature studies on accelerator programs are also very few and even insufficient [10], [23], [24]). According to Cohen and Hochberg [10], there are several reasons for this. The first of these reasons is that some programs that contain the word accelerator are not actually an accelerator but are essentially an incubator center, so researchers have to look for the actual accelerator program to work. This problem was also encountered during this study. Another reason is that the accelerator programs are quite new so do not have sufficient data. Another reason for Albort-Morant and Oghazi [23] is that start-up companies participating in accelerators are early stage companies and often do not have enough data to work. Finally, not all companies taking part in the accelerator program are always able to continue their lives and some of them are closed in the first 5 years. This makes it difficult for researchers to collect data.

In the next section, hypotheses of this study will be indicated. Section 3 describes the methodology and hypotheses used in this study. Section 4 clarifies the results and explains the findings. Finally, Section 5 discusses the conclusions, limitations of this study and future work opportunities.

\section{Methods And Hypotheses DeVelopment}

This research concentrates on 8 accelerator programs. These programs differ from each other in terms of how they are supported. ITU Seed, Kworks and SuCool are programs supported by government organizations in addition to universities. ITU Seed is within the structure of Istanbul
Technical University, Kworks is within the organization of Koc University and SuCool is within the structure of Sabanci University. Pilot, Albaraka Garaj and Lonca are programs supported by corporations. Pilot is founded by Turkish Telecom, Albaraka Garaj is founded by Albaraka Turk Bank and Lonca is founded by Kuveyt Turk Bank. Starter's Hub and IOT Telco Labs are hybrid programs. They are supported by a few different organizations. Starter's Hub is supported by Gedik Invesment and Murat Vargi Holding. IOT Telco Labs is supported by Nexus Ventures and Istanbul Startup Angels investor network. Corporations prefer to support accelerators in order to reach new ideas and innovations which will help them grow and renew themselves [25]. In this way, they can also get connected with entrepreneurs and increase their talent pool.

The aim of this study is analyzing which demographics of entrepreneurs raise or reduce the need for support from accelerator programs and the benefits they obtain from these programs. The demographics of entrepreneurs that are taken into consideration in this study are age, gender, professional work experience, educational status, and to have an entrepreneur in the family or social circle. The accelerator supports are compared according to the entrepreneur demographics. As a result of this study, accelerators can alter their programs in order to fulfill entrepreneurs' needs and help them grow their businesses.

Previous studies made with entrepreneurs examine if the capacity of the company and human capital change the necessity to obtain support from the incubators or not [4], [26]. Rather than incubators and the human resources, this research concentrates on entrepreneurs currently present on accelerator programs and looks at entrepreneurs' demographics to analyze which supports and services entrepreneurs need the most in terms of their gender, age, educational status, work experience and family background. Moreover, majority of researches related to incubation and accelerator programs lack a consistent theory [27] and are largely descriptive in nature [10], [12]. Thus, in this study, an experimental framework is used and the below proposals are analyzed. This study is built upon the previous studies of [28], [29] and therefore, uses the same survey data.

\section{A. Research Design and Hypotheses}

In this study, the propositions are designed based on the model as shown in Fig. 1. In this model, it will be investigated whether the characteristics of the entrepreneur affect the utilization level of the services provided in the accelerator program and the level of receiving benefit for the development of the company. 


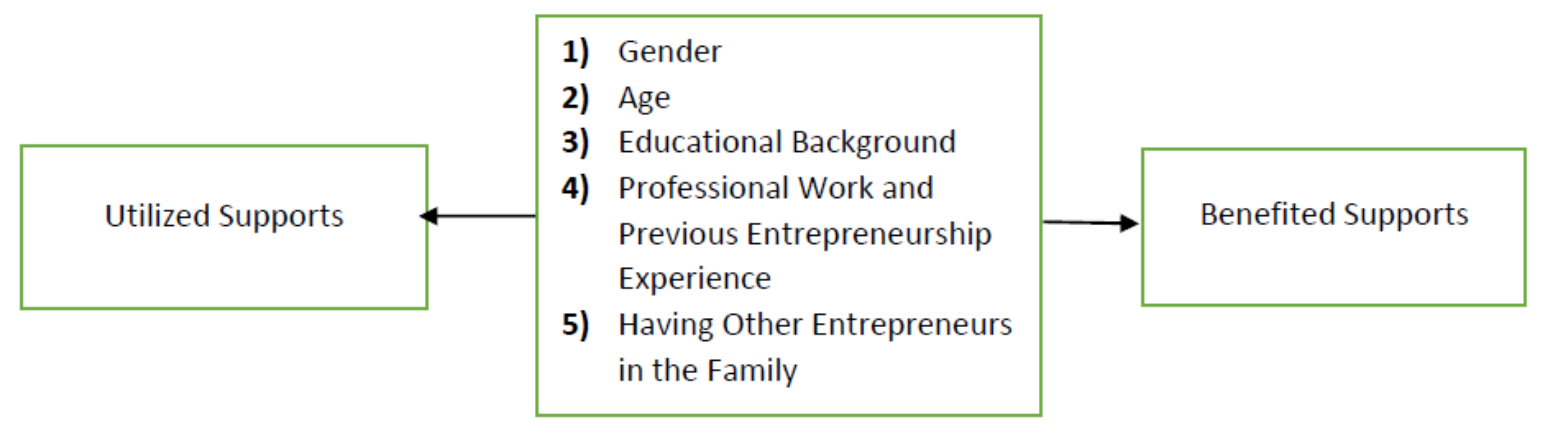

Fig. 1. Research Design.

There is historically inherited male dominance and this causes a huge gender gap on entrepreneurship. Berglann et al. [30] state that only $25 \%$ of entrepreneurs are female. Moreover, the degree of female businesspersons establishing a technology business is only $5 \%$, as stated by a survey implemented by Women who Tech in 2012 [31]. As indicated by authors Carrasco and Cuevas [32], Hechavarria and Reynolds [33], Thach and Kidwell [34], the amount of female entrepreneurs is growing every year. Nevertheless, in comparison to other sectors the rate of female entrepreneurs in technology is much lower. The reason of this is that women are underrepresented in science, technology, engineering, and mathematics (STEM) jobs [35], [36], [37], [38]. Stoet and Geary [39] made a study researching the gender equality paradox in STEM. According to their research, countries with lower level of gender equality had relatively more women among STEM graduates than did more gender equal countries. This is interesting to point out because gender-equal countries are those that give women more educational and empowerment opportunities, and mostly promote women's engagement in STEM fields [40]. Another reason why there are less women entrepreneurs is that the motives for starting a business for women and men are very different. Women start businesses [41] to earn their freedom and get fulfillment in their jobs [42], whereas men start businesses to have a better job and receive more earnings. Considering men and women are physiologically different than each other, they may need different supports to grow their businesses because genderrelated psychological traits related to managerial differences do exist [43].

Ha1: The supports that men and women use the most in accelerator programs are different. They utilize different supports.

Ha2: The supports from accelerator programs that men and women benefit the most are different.

Entrepreneurs' ages have dropped in the last few years. Studies which observe the effects of age on entrepreneurship by analyzing young entrepreneurs already exist. These researches were performed by Levesque and Minniti [44], Montes Rojas and Siga [45] and Thomas [46]. Young people are eager to take more risks than older people and therefore, they have a tendency to be entrepreneurs [44]. Young people are more courageous and energetic and thus, more willing to take on the risk of founding a new business according to Blanchflower and Meyer [47]. It gets more problematic for individuals to found a new business as they age because the things they need to give up and their responsibilities grow concurrently with their ages. Unless they are unemployed or find themselves a prospect to become an entrepreneur, they are less likely to found a new venture [25].

Hb1: The need for support from the accelerator program drops as the entrepreneur ages.

Hb2: The benefit it gets from the supports of accelerator program declines as the entrepreneur ages.

Entrepreneurs can gain some of the skills they need such as business management, leadership, technical and behavioral skills through formal education. Nonetheless, there are contradictory researches about the consequences of education on entrepreneurial approaches. According to Shapero [48], Fallows [49], Ronstadt [50], Laukkanen [51], Peterman and Kennedy [52] and $\mathrm{Wu}$ and $\mathrm{Wu}$ [53], the higher education an individual has, the less likely this individual will launch a new venture. Authors state a few reasons for this. The first one is that an individual with a degree can find a better job as an employee. The second one is that formal education increases the rate of avoiding risks and decreases curiosity as well as the tolerance of dealing with ambiguity. Moreover, there are some schools which specifically encourage their students to work in large corporations instead of small businesses. Alternatively, some other studies propose that higher education has a positive impact on entrepreneurship. These studies are performed by Robinson and Sexton [54], Davidsson and Honig [55], Ilhan Ertuna and Gurel [56]. This means an individual with higher education will more likely to found a new business.

Hc1: The need for support from the accelerator program declines as the level of education of the entrepreneur rises.

Hc2: The benefit it receives from the supports of accelerator program declines as the level of education of the entrepreneur rises.

Theoretical education cannot give the ability to make better decisions, only experience can. Organizational skills that come with experience can only be gained by working as an employee in a corporation [25]. In addition, it is difficult to learn how to run a company without working as a manager or without observing your managers. According to Mintzberg [57], the best way to learn how to run a company is through acquiring direct experience. Else, an individual cannot realize all of the aspects of running a business. Therefore, a person 
without any managerial knowledge should get more support to run a new foundation.

Hd1: The supports that entrepreneurs with professional work experience and without any professional work experience make the most use of from accelerator programs are different.

Hd2: The supports that entrepreneurs with professional work experience and without any professional work experience benefit the most from accelerator programs are different.

He1: The supports that entrepreneurs with previous entrepreneurship experience in any sector and without any experience make the most use of from accelerator programs are different.

He2: The supports that entrepreneurs with previous entrepreneurship experience in any sector and without any experience benefit the most from accelerator programs are different.

Having an entrepreneur in the immediate family encourage individuals to found a new venture through the help they get from their families. If an individual has an entrepreneur family member, this individual is more likely to start a new venture. Authors such as Albort-Morant and Oghazi [25], Gurel et al. [58] and Singh et al. [59] also support this argument. Having an entrepreneur within the immediate family has a greater effect than having an entrepreneur as an acquaintance. There is a simple reason behind this. Entrepreneurial families also encourage their children to start new businesses because they can guide them through the obstacles they will come across during their entrepreneurship journeys. Since the new entrepreneur can take advantage from the experiences of their families, they can be one step ahead compared to others who doesn't have any entrepreneurs within their families.

Hf1: The lack of an entrepreneur in the entrepreneur's family grows the need for support from the accelerator program.

Hf2: The lack of an entrepreneur in the entrepreneur's family grows the benefit it takes from the accelerator program.

\section{B. Survey Data}

The data of this study were collected by a survey which was conducted to entrepreneurs in the selected accelerator programs between September and December, 2017. The reliability and validity analysis of the survey is performed. The reliability analysis is done using Cronbach's Alpha method and the value of $\alpha$ for this survey is 0.891 meaning that the survey is very reliable. The content validity analysis is done by asking the feedback of two experts in the field and according to their reviews, the survey was revised. Afterwards, this initially prepared survey was distributed to the entrepreneurs attended in other accelerator programs. In the initial survey, it was analyzed whether the entrepreneurs understood the questions in the way they were supposed to be asked and answered accordingly. In relation to the results of this survey, the questions were reviewed and applied to the same group again. In relation to the results attained, the survey was revised once more and implemented to entrepreneurs who were selected randomly in the target group. This establishes our pilot group of entrepreneurs. Later on, this survey was updated and finalized. As a result, the 4th version of the survey is its final version.

After the final version of the survey is prepared, the coordinators of the chosen accelerator programs were called and a time was scheduled to go to the offices of the accelerator programs in order to collect data from the entrepreneurs. Hard copy of the survey was handed out to entrepreneurs who were present during the visits to collect data. Then, these data were transmitted to the electronic environment. SurveyMonkey is used to bring together data electronically from the entrepreneurs who completed the programs and not present in the time of the visit to the offices of the programs. The link of the survey is first sent to the coordinators of the programs and these coordinators sent the link to the remaining entrepreneurs. Also, the link was posted in in social media groups of our targeted accelerator programs and in other entrepreneurship groups in order to collect more data for the study.

The survey consists of 4 different sections. These are information about entrepreneurs, information about the startup, information about the accelerator and information about the entrepreneur who left the accelerator program. The last section was only filled out by entrepreneurs who graduated from the accelerator program. The survey questions consist of open ended, multiple choice and 5 point likert scale questions. The hypotheses are measured according to the 5 point likert scale questions.

Totally, 162 people participated into our survey but 130 of them filled it out completely. Out of these 130 entrepreneurs, 5 of them were excluded from the study because they had participated in different accelerator programs outside of the targeted ones. These 125 entrepreneurs belong to 106 different startups. The number of men attended the survey is 103 and the number of women is 22 . The data received is checked for common method bias using Harman's single factor analysis in Table I. The variance explained by a single factor is $30.038 \%$ which is less than $50 \%$. Thus, it can be determined that the data set don't suffer from the common method bias issue.

TABLE I. HARMAN'S SINGLE FACTOR ANALYSIS.

\begin{tabular}{|l|l|l|l|l|l|l|}
\hline \multicolumn{3}{|c|}{ Initial Eigenvalues } & \multicolumn{3}{l|}{$\begin{array}{l}\text { Extraction Sums of Squared } \\
\text { Loadings }\end{array}$} \\
\hline $\begin{array}{l}\text { Comp } \\
\text { onent }\end{array}$ & Total & $\begin{array}{l}\text { \% of } \\
\text { Varian } \\
\text { ce }\end{array}$ & $\begin{array}{l}\text { Cumulati } \\
\text { ve } \%\end{array}$ & Total & $\begin{array}{l}\text { \% of } \\
\text { Varianc } \\
\text { e }\end{array}$ & $\begin{array}{l}\text { Cumulativ } \\
\text { e \% }\end{array}$ \\
\hline $\mathbf{1}$ & 2,103 & 30,038 & 30,038 & 2,103 & 30,038 & 30,038 \\
\hline $\mathbf{2}$ & 1,485 & 21,210 & 51,249 & & & \\
\hline $\mathbf{3}$ & 1,201 & 17,151 & 68,400 & & & \\
\hline $\mathbf{4}$ & 0,781 & 11,161 & 79,561 & & & \\
\hline $\mathbf{5}$ & 0,667 & 9,533 & 89,094 & & & \\
\hline $\mathbf{6}$ & 0,530 & 7,571 & 96,665 & & & \\
\hline $\mathbf{7}$ & 0,233 & 3,335 & 100,000 & & & \\
\hline Extraction Method: Principal Component Analysis & & \\
\hline
\end{tabular}




\section{RESUlts}

The tests of hypotheses and the outcomes of these tests can be found below. Descriptive statistical methods are used to evaluate the study data. In addition to graphical tests, normal distributions of quantitative data are tested using the ShapiroWilk test. In order to compare the two groups of quantitative variables that are not normally distributed, Mann-Whitney $U$ test is used. The Kruskal-Wallis test is performed to compare more than two groups of quantitative variables which are not normally distributed. Dunn-Bonferroni test is used to find out the groups that produced significance, if the Kruskal-Wallis test result is significant. In this section, first level " 1 " hypotheses are tested meaning hypotheses from Ha1 to Hf1. The results of these tests can be found starting from Table II to Table VII. Next, level "2" hypotheses are tested meaning hypotheses from Ha2 to Hf2. The results of these tests can be found starting from Table VIII to Table XIX.

After the univariate analyses, GLMM (generalized linear mixed models) are used in the next section to evaluate the effects of data on support utilization levels of entrepreneurs. Factors affecting each support are evaluated individually in univariate analyses. In models, it is aimed to study the effects of multiple factors on utilization levels together. The results of these tests can be found starting from Table XIX to Table XXVIII.

The supports of accelerators that are going to be analyzed in this study are respectively training, mentorship, office, laboratory, advertising, networking, investment/finance, meeting with investors, going abroad, trademark registration/ patent application/ legal counseling, collaborating with organizations that support the accelerator and technical support because these are the supports that are commonly provided by accelerators. Only the supports that have significant utilization or benefit level differences according to the demographics of entrepreneurs are presented in the study. For example; training and mentorship supports do not have any significant differences in their utilization levels according to the demographics of entrepreneurs. Therefore, Table II represents the next support which is providing an office to the entrepreneur.

\section{A. Univariate Analyses}

Demographics that are taken into consideration for this study are gender, age, education, professional work experience and having an entrepreneur in the family or social circle. In the univariate analyses, only the demographics that produce significant results $(p<0.05)$ are presented. For example, in Table II, only the effects of age and to have an entrepreneur in the family or social circle is presented because they have significant results on utilization of office services.

In relation to the age (p: 0.045) in Table II, it is significantly different in terms of the usage level of office services. The usage level of entrepreneurs 35 years old and above is lower than the ones under 25 years old (p: 0.049). There is also a significant difference in terms of having an entrepreneur within the family (p:0.031). The office usage level of entrepreneurs without an entrepreneur in their families or social circle is lower than the ones who have entrepreneurs in their families or social circle. The reason of this may be that entrepreneurs with other entrepreneurs in their families know the importance of working in an office more than others. Entrepreneurs who do not have entrepreneurs in their families can also use coffee shops or libraries to work.

In relation to the previous work experiences of entrepreneurs, it is significantly different in terms of the usage level of networking services (p:0.019) in Table III. The utilization level of entrepreneurs with 1-2 years of work experience is higher than the ones with 8 years and more work experience (p:0.045). Someone with 8 years or more experience is expected to have a larger professional network compared to someone with less experience. Therefore, entrepreneurs with more work experience uses the networking support the accelerator provides less than entrepreneurs with fewer work experience.

In Table IV, in respect of the utilization level of going abroad opportunities according to the age (p:0.031), is significantly different. The utilization level of entrepreneurs under 25 years old is higher than the ones between 31 and 35 years old (p: 0.021). This is because as people age, their responsibilities increase as well. For this reason, they do not prefer to go abroad and establish a new life from scratch since going abroad is another risk for entrepreneurs besides founding a new company.

TABLE II. COMPARING THE LEVEL OF UTILIZATION OF OFFICE SERVICES ACCORDING TO THE DEMOGRAPHICS OF THE ENTREPRENEUR

\begin{tabular}{|c|c|c|c|c|c|}
\hline \multirow{2}{*}{\multicolumn{2}{|c|}{ (n:125) }} & \multirow{3}{*}{$\begin{array}{l}\text { n } \\
40\end{array}$} & \multirow{3}{*}{$\begin{array}{l}\begin{array}{l}\text { Office } \\
\text { Services }\end{array} \\
\begin{array}{l}\text { Median (Q1, } \\
\text { Q3) }\end{array} \\
5(4,5)\end{array}$} & \multirow{3}{*}{$\begin{array}{l}\begin{array}{l}\text { Test } \\
\text { value }\end{array} \\
8.041\end{array}$} & \multirow{3}{*}{$\begin{array}{l}\mathbf{p} \\
{ }^{\mathrm{a}} 0.045^{*}\end{array}$} \\
\hline & & & & & \\
\hline \multirow{4}{*}{ Age } & $<25$ & & & & \\
\hline & $26-30$ & 42 & $4.5(3,5)$ & & \\
\hline & $31-35$ & 27 & $4(3,5)$ & & \\
\hline & $>35$ & 16 & $4(2,4.5)$ & & \\
\hline \multirow{2}{*}{$\begin{array}{l}\text { There is an } \\
\text { Entrepreneur in } \\
\text { the Family or } \\
\text { Social Circle }\end{array}$} & Yes & 86 & $5(4,5)$ & -2.157 & b0.031* \\
\hline & No & 39 & $4(3,5)$ & & \\
\hline
\end{tabular}

TABLE III. COMPARING THE LEVEL OF UTILIZATION OF NETWORKING SERVICES ACCORDING TO THE DEMOGRAPHICS OF THE ENTREPRENEUR

\begin{tabular}{|c|c|c|c|c|c|}
\hline \multirow{2}{*}{\multicolumn{2}{|c|}{ (n:125) }} & \multirow{2}{*}{ n } & Networking & \multirow{2}{*}{$\begin{array}{l}\text { Test } \\
\text { value }\end{array}$} & \multirow{2}{*}{$\mathbf{p}$} \\
\hline & & & Median (Q1, Q3) & & \\
\hline \multirow{5}{*}{$\begin{array}{l}\text { Professional } \\
\text { Work } \\
\text { Experience }\end{array}$} & None & 15 & $4(4,4)$ & 11.735 & ${ }^{\mathrm{a}} 0.019 *$ \\
\hline & $1-2$ years & 25 & $4(3,5)$ & & \\
\hline & $3-5$ years & 28 & $4(3,4)$ & & \\
\hline & 6-7 years & 14 & $4(4,5)$ & & \\
\hline & $\begin{array}{l}8 \text { years } \\
\text { and above }\end{array}$ & 43 & $3(3,4)$ & & \\
\hline
\end{tabular}


TABLE IV. COMPARING THE LEVEL OF UTILIZATION OF GOING ABROAD SERVICES ACCORDING TO THE DEMOGRAPHICS OF THE ENTREPRENEUR

\begin{tabular}{|c|c|c|c|c|c|}
\hline \multirow{2}{*}{\multicolumn{2}{|c|}{ (n:125) }} & \multirow[t]{2}{*}{$\mathbf{n}$} & $\begin{array}{l}\text { Going } \\
\text { Abroad } \\
\text { Services }\end{array}$ & \multirow{2}{*}{$\begin{array}{l}\text { Test } \\
\text { value }\end{array}$} & \multirow{2}{*}{$\mathbf{p}$} \\
\hline & & & $\begin{array}{l}\text { Median } \\
\text { (Q1, Q3) }\end{array}$ & & \\
\hline \multirow{4}{*}{ Age } & $<25$ & 40 & $3(0.5,4)$ & 8.863 & ${ }^{\mathrm{a}} 0.031 *$ \\
\hline & $26-30$ & 42 & $2(0,4)$ & & \\
\hline & $31-35$ & 27 & $1(0,2)$ & & \\
\hline & $>35$ & 16 & $1(0.5,3)$ & & \\
\hline \multirow{5}{*}{$\begin{array}{l}\text { Professional } \\
\text { Work } \\
\text { Experience }\end{array}$} & None & 15 & $3(0,5)$ & 11.221 & ${ }^{\mathrm{a}} 0.024 *$ \\
\hline & $\begin{array}{l}1-2 \\
\text { years }\end{array}$ & 25 & $3(1,4)$ & & \\
\hline & $\begin{array}{l}3-5 \\
\text { years }\end{array}$ & 28 & $1(0,3.5)$ & & \\
\hline & $\begin{array}{l}6-7 \\
\text { years }\end{array}$ & 14 & $0.5(0,2)$ & & \\
\hline & $\begin{array}{l}8 \text { years } \\
\text { and } \\
\text { above }\end{array}$ & 43 & $1(0,3)$ & & \\
\hline
\end{tabular}

It is significantly different according to the professional work experiences of entrepreneurs (p:0.024) in Table IV. The usage level of entrepreneurs with 1-2 years of work experience is higher than the ones with 6-7 years of work experience (p:0.043). As entrepreneurs' experience and ability increases, the willingness to take risks decreases. Entrepreneurs with less experience and who are younger prefer to go abroad in order to move their careers forward in a short time.

It is significantly different in terms of the usage level of patent application, legal counseling services and trademark registration according to the age (p:0.022) in Table V. The utilization level of entrepreneurs under 25 years old is higher than the ones between 31 and 35 years old and above 35 years old (correspondingly, p:0.048, p:0.048). Also, it is significantly different in terms of the educational status of entrepreneurs ( $\mathrm{p}: 0.004)$. The utilization level of entrepreneurs with Bachelor's degrees is higher than the ones with Master's degrees (p:0.003). The reason of this may be that entrepreneurs with Master's degrees have already taken classes or seminars about how to register trademarks or apply for patents and thus, they use the support provided by the accelerator program less.

It is significantly different in terms of using the support of collaborating with organizations in relation to the age (p:0.027) in Table VI. The usage level of entrepreneurs under 25 years old is higher than the ones between 31 and 35 years old (p:0.049). Also, statistically significant difference is found in respect of the educational status of entrepreneurs (p:0.024). The usage level of entrepreneurs with Bachelor's degrees is higher than the ones with Master's degrees (p:0.027). Entrepreneurs who are older and more educated are expected to have more network compared to others. Therefore, they can reach more clients and do not need to collaborate with the organizations that support the accelerator compared to younger and less educated entrepreneurs.
TABLE V. COMPARING THE LEVEL OF UTILIZATION OF TRADEMARK REgISTRATION / PATENT APPLICATION / LEGAL COUNSELING SERVICES ACCORDING TO THE DEMOGRAPHICS OF THE ENTREPRENEUR

\begin{tabular}{|c|c|c|c|c|c|}
\hline \multirow{2}{*}{\multicolumn{2}{|c|}{ (n:125) }} & \multirow[t]{2}{*}{$\mathbf{n}$} & $\begin{array}{l}\text { Trademark } \\
\text { Registration } \\
\text { Services } \\
\end{array}$ & \multirow{2}{*}{$\begin{array}{l}\text { Test } \\
\text { value }\end{array}$} & \multirow[t]{2}{*}{$\mathbf{p}$} \\
\hline & & & $\begin{array}{l}\text { Median (Q1, } \\
\text { Q3) }\end{array}$ & & \\
\hline \multirow{4}{*}{ Age } & $<25$ & 40 & $3(1.5,4)$ & 9.678 & $\mathrm{a} 0.022 *$ \\
\hline & $26-30$ & 42 & $2(1,3)$ & & \\
\hline & $31-35$ & 27 & $2(0,3)$ & & \\
\hline & $>35$ & 16 & $1(0,3)$ & & \\
\hline \multirow{3}{*}{$\begin{array}{l}\text { Educational } \\
\text { Status }\end{array}$} & $\begin{array}{l}\text { Before } \\
\text { Bachelor's }\end{array}$ & 16 & $3(1.5,3)$ & 10.831 & ${ }^{\mathrm{a}} 0.004^{* *}$ \\
\hline & Bachelor's & 82 & $3(1,4)$ & & \\
\hline & $\begin{array}{l}\text { Master's } \\
\text { and up }\end{array}$ & 27 & $1(0,2)$ & & \\
\hline
\end{tabular}

TABLE VI. COMPARING THE LEVEL OF UTILIZATION OF COLLABORATING WITH ORGANIZATIONS THAT SUPPORT THE ACCELERATOR SERVICES ACCORDING TO THE DEMOGRAPHICS OF THE ENTREPRENEUR

\begin{tabular}{|c|c|c|c|c|c|}
\hline \multirow{2}{*}{\multicolumn{2}{|c|}{ (n:125) }} & \multirow[t]{2}{*}{$\mathbf{n}$} & $\begin{array}{l}\text { Collaborating } \\
\text { with } \\
\text { Organizations } \\
\text { Services }\end{array}$ & \multirow[t]{2}{*}{$\begin{array}{l}\text { Test } \\
\text { value }\end{array}$} & \multirow[t]{2}{*}{$\mathbf{p}$} \\
\hline & & & $\begin{array}{l}\text { Median (Q1, } \\
\text { Q3) }\end{array}$ & & \\
\hline \multirow{4}{*}{ Age } & $<25$ & 40 & $4(3,4.5)$ & 9.147 & ${ }^{\mathrm{a}} 0.027 *$ \\
\hline & $26-30$ & 42 & $3(2,4)$ & & \\
\hline & $31-35$ & 27 & $3(1,4)$ & & \\
\hline & $>35$ & 16 & $2.5(0.5,4.5)$ & & \\
\hline \multirow{3}{*}{$\begin{array}{l}\text { Educational } \\
\text { Level }\end{array}$} & $\begin{array}{l}\text { Pre- } \\
\text { Bachelor's }\end{array}$ & 16 & $3(3,4.5)$ & 7.444 & ${ }^{\mathrm{a}} 0.024 *$ \\
\hline & Bachelor's & 82 & $3(2,4)$ & & \\
\hline & and up & 27 & $3(1,3)$ & & \\
\hline
\end{tabular}

TABLE VII. COMPARING THE LEVEL OF UTILIZATION OF TECHNICAL SUPPORT SERVICES ACCORDING TO THE DEMOGRAPHICS OF THE ENTREPRENEUR

\begin{tabular}{|c|c|c|c|c|c|}
\hline \multirow[t]{2}{*}{ (n:125) } & & \multirow[t]{2}{*}{$\mathbf{n}$} & $\begin{array}{l}\text { Technical } \\
\text { Support } \\
\text { Services }\end{array}$ & \multirow{2}{*}{$\begin{array}{l}\text { Test } \\
\text { value }\end{array}$} & \multirow{2}{*}{$\mathbf{p}$} \\
\hline & & & $\begin{array}{l}\text { Median } \\
\text { (Q1, Q3) }\end{array}$ & & \\
\hline \multirow{4}{*}{ Age } & $<25$ & 40 & $2(1,4)$ & 13.349 & ${ }^{\mathrm{a}} 0.004^{* *}$ \\
\hline & $26-30$ & 42 & $3(2,4)$ & & \\
\hline & $31-35$ & 27 & $1(1,3)$ & & \\
\hline & $>35$ & 16 & $1(0,3)$ & & \\
\hline \multirow{3}{*}{$\begin{array}{l}\text { Educational } \\
\text { Status }\end{array}$} & $\begin{array}{l}\text { Pre- } \\
\text { Bachelor's }\end{array}$ & 16 & $2(1,3.5)$ & 8.956 & ${ }^{\mathrm{a}} 0.011^{*}$ \\
\hline & Bachelor's & 82 & $3(1,4)$ & & \\
\hline & $\begin{array}{l}\text { Master's } \\
\text { and up }\end{array}$ & 27 & $1(0,3)$ & & \\
\hline
\end{tabular}

${ }^{\mathrm{a}}$ Kruskal Wallis test $\quad{ }^{*} \mathrm{p}<0.05 * * \mathrm{p}<0.01$

Q1: First quarter, Q3: Third Quarter 
In terms of the usage level of technical support, it is significantly different according to the age (p:0.004) in Table VII. The utilization level of entrepreneurs between 25 and 30 years old is higher than between 31 and 35 years old and above 35 years old (correspondingly, p:0.015, p:0.021). Also, it is significantly different according to the educational status of entrepreneurs (p:0.011). The utilization level of entrepreneurs with Bachelor's degrees is higher than the ones with Master's degrees (p:0.008). This is also very similar to the above results. It can be understood from these analyses that as the age and educational status of entrepreneurs increase, they use the supports of the accelerator programs less.

According to the above analyses and results seen from Table II to Table VII, no statistically significant difference is found in the utilization of accelerator supports between men and women. In relation to the age of entrepreneurs, a significant difference is found in the use of office, going abroad, trademark registration, collaborating with other organizations and technical supports. In terms of the educational status of entrepreneurs, a significant difference is found in the utilization levels of trademark registration, collaborating with other organizations and technical supports. In terms of the previous professional work experience of entrepreneurs, a significant difference is found in the use of networking and going abroad services. It is not significantly different in terms of the utilization of any of the accelerator supports in relation to the previous entrepreneurship experience of entrepreneurs. In relation to having an entrepreneur within the close family or social circle, a statistically difference is found in the usage of office services.

It is significantly different in terms of benefiting from training services according to educational background ( $\mathrm{p}$ : 0.035 ) in Table VIII. The benefit level of entrepreneurs with Master's degrees and up is lower than the ones with Bachelor's degrees (p:0.046). The reason of this is because entrepreneurs with higher degrees probably took similar classes in schools and already know the subjects explained in the accelerator program or they can learn these subjects by themselves through researching. Also, it is significantly different according to the social circle of entrepreneur (p:0.038). The benefit level of entrepreneurs without an entrepreneur in their families or social circle is higher than the ones with entrepreneurs in their families or social circle. Entrepreneurs with other entrepreneurs in their families can learn these subjects with the help of their families so they don't benefit as much as the others.

It is significantly different in terms of benefiting from mentoring services according to the age of the entrepreneur (p: 0.011 ) in Table IX. The benefit level of entrepreneurs between 31 and 35 years old is lower than the ones between 26 and 30 years old (p: 0.013). Also, it is significantly different according to the social circle of entrepreneur (p:0.040). The benefit level of entrepreneurs without an entrepreneur in their families or social circle is higher than the ones with entrepreneurs in their families or social circle. Entrepreneurs without other entrepreneurs in their families can get mentoring support from their families so they don't benefit from this support as much as the others.
It is significantly different according to getting benefit from office services according to the educational background (p: 0.015) in Table X. The benefit level of entrepreneurs with pre-Bachelor's degrees is higher than the ones with Master's degrees and up (p:0.028).

It is significantly different according to getting benefit from laboratory services according to age of the entrepreneur (p:0.049) in Table XI. The benefit level of entrepreneurs between 31 and 35 years old is lower than the ones between 26 and 30 years old (p:0.048).

TABLE VIII. COMPARISON OF THE LEVEL OF RECEIVING BENEFIT FROM THE TRAINING SERVICE TO THE DEVELOPMENT OF THE COMPANY ACCORDING TO THE DEMOGRAPHICS OF THE ENTREPRENEUR

\begin{tabular}{|c|c|c|c|c|c|}
\hline \multirow{2}{*}{\multicolumn{2}{|c|}{ (n:125) }} & \multirow{3}{*}{$\begin{array}{l}\mathbf{n} \\
16\end{array}$} & \multirow{3}{*}{$\begin{array}{l}\text { Training } \\
\begin{array}{l}\text { Median } \\
(\mathbf{Q} 1, \mathbf{Q 3})\end{array} \\
4.5(3,5)\end{array}$} & \multirow{3}{*}{$\begin{array}{l}\begin{array}{l}\text { Test } \\
\text { value }\end{array} \\
6.697\end{array}$} & \multirow{3}{*}{$\begin{array}{l}\mathbf{p} \\
{ }^{\mathrm{a}} 0.035^{*}\end{array}$} \\
\hline & & & & & \\
\hline \multirow{3}{*}{$\begin{array}{l}\text { Educational } \\
\text { Status }\end{array}$} & $\begin{array}{l}\text { Before } \\
\text { Bachelor's }\end{array}$ & & & & \\
\hline & Bachelor's & 82 & $4(3,5)$ & & \\
\hline & $\begin{array}{l}\text { Master's } \\
\text { and up }\end{array}$ & 27 & $3(2,4)$ & & \\
\hline \multirow{2}{*}{$\begin{array}{l}\text { There is an } \\
\text { Entrepreneur in } \\
\text { the Family or } \\
\text { Social Circle }\end{array}$} & Yes & 86 & $4(3,4)$ & -2.079 & b0.038* \\
\hline & No & 39 & $4(3,5)$ & & \\
\hline
\end{tabular}

TABLE IX. COMPARISON OF THE LEVEL OF RECEIVING BENEFIT FROM THE MENTORING SERVICE TO THE DEVELOPMENT OF THE COMPANY ACCORDING TO THE DEMOGRAPHICS OF THE ENTREPRENEUR

\begin{tabular}{|c|c|c|c|c|c|}
\hline \multirow{2}{*}{\multicolumn{2}{|c|}{ (n:125) }} & \multirow[b]{2}{*}{$\mathbf{n}$} & Mentoring & \multirow{2}{*}{$\begin{array}{l}\text { Test } \\
\text { value }\end{array}$} & \multirow[b]{2}{*}{$\mathbf{p}$} \\
\hline & & & $\begin{array}{l}\text { Median (Q1, } \\
\text { Q3) }\end{array}$ & & \\
\hline \multirow{4}{*}{ Age } & $<25$ & 40 & $4(4,5)$ & 11.057 & ${ }^{\mathrm{a}} 0.011 *$ \\
\hline & $26-30$ & 42 & $4(4,5)$ & & \\
\hline & $31-35$ & 27 & $4(3,4)$ & & \\
\hline & $>35$ & 16 & $4(3,5)$ & & \\
\hline \multirow{2}{*}{$\begin{array}{l}\text { There is an } \\
\text { Entrepreneur in } \\
\text { the Family or } \\
\text { Social Circle }\end{array}$} & Yes & 86 & $4(3,5)$ & 2.053 & b $0.040 *$ \\
\hline & No & 39 & $4(4,5)$ & & \\
\hline
\end{tabular}

TABLE X. COMPARISON OF THE LEVEL OF RECEIVING BENEFIT FROM THE OFFICE SERVICE TO THE DEVELOPMENT OF THE COMPANY ACCORDING TO THE DEMOGRAPHICS OF THE ENTREPRENEUR

\begin{tabular}{|c|c|c|c|c|c|}
\hline \multirow[b]{2}{*}{ (n:125) } & & \multirow[b]{2}{*}{$\mathbf{n}$} & Office & \multirow{2}{*}{$\begin{array}{l}\text { Test } \\
\text { value }\end{array}$} & \multirow[b]{2}{*}{$\mathbf{p}$} \\
\hline & & & $\begin{array}{l}\text { Median } \\
(Q 1, Q 3)\end{array}$ & & \\
\hline \multirow{3}{*}{$\begin{array}{l}\text { Educational } \\
\text { Status }\end{array}$} & $\begin{array}{l}\text { Before } \\
\text { Bachelor's }\end{array}$ & 16 & $4(2.5,4)$ & 8.366 & ${ }^{\mathrm{a}} 0.015^{*}$ \\
\hline & Bachelor's & 82 & $4(4,5)$ & & \\
\hline & $\begin{array}{l}\text { Master's } \\
\text { and up }\end{array}$ & 27 & $3(2,4)$ & & \\
\hline
\end{tabular}


TABLE XI. COMPARISON OF THE LEVEL OF RECEIVING BENEFIT FROM THE LABORATORY SERVICE TO THE DEVELOPMENT OF THE COMPANY ACCORDING TO THE DEMOGRAPHICS OF THE ENTREPRENEUR

\begin{tabular}{|c|c|c|c|c|c|}
\hline \multirow{2}{*}{\multicolumn{2}{|c|}{ (n:125) }} & \multirow{3}{*}{$\begin{array}{l}\text { n } \\
40\end{array}$} & \multirow{3}{*}{$\begin{array}{l}\text { Laboratory } \\
\begin{array}{l}\text { Median (Q1, } \\
\text { Q3) }\end{array} \\
1(0,2)\end{array}$} & \multirow{3}{*}{$\begin{array}{l}\begin{array}{l}\text { Test } \\
\text { value }\end{array} \\
7.837\end{array}$} & \multirow{3}{*}{$\begin{array}{l}\mathbf{p} \\
{ }^{\mathrm{a}} 0.049^{*}\end{array}$} \\
\hline & & & & & \\
\hline \multirow{4}{*}{ Age } & $<25$ & & & & \\
\hline & 26-30 & 42 & $1(0,4)$ & & \\
\hline & 31-35 & 27 & $0(0,1)$ & & \\
\hline & $>35$ & 16 & $0(0,1)$ & & \\
\hline
\end{tabular}

TABLE XII. COMPARISON OF THE LEVEL OF GETTING BENEFIT FROM THE ADVERTISING SERVICE TO THE DEVELOPMENT OF THE COMPANY ACCORDING TO THE DEMOGRAPHICS OF THE ENTREPRENEUR

\begin{tabular}{|c|c|c|c|c|c|}
\hline \multirow{2}{*}{\multicolumn{2}{|c|}{ (n:125) }} & \multirow{3}{*}{$\begin{array}{l}\text { n } \\
40\end{array}$} & \multirow{3}{*}{$\begin{array}{l}\text { Advertising } \\
\begin{array}{l}\text { Median (Q1, } \\
\text { Q3) }\end{array} \\
3(1,4)\end{array}$} & \multirow{3}{*}{$\begin{array}{l}\begin{array}{l}\text { Test } \\
\text { value }\end{array} \\
8.168\end{array}$} & \multirow{3}{*}{$\begin{array}{l}\mathbf{p} \\
{ }^{\mathrm{a}} 0.043^{*}\end{array}$} \\
\hline & & & & & \\
\hline \multirow{4}{*}{ Age } & $<25$ & & & & \\
\hline & $26-30$ & 42 & $3(2,5)$ & & \\
\hline & $31-35$ & 27 & $2(1,3)$ & & \\
\hline & $>35$ & 16 & $2(1,4)$ & & \\
\hline \multirow{3}{*}{$\begin{array}{l}\text { Educational } \\
\text { Status }\end{array}$} & $\begin{array}{l}\text { Pre- } \\
\text { Bachelor's }\end{array}$ & 16 & $1.5(0,2.5)$ & 10.002 & ${ }^{\mathrm{a}} 0.007 * *$ \\
\hline & Bachelor's & 82 & $3(1,4)$ & & \\
\hline & $\begin{array}{l}\text { Master's } \\
\text { and up }\end{array}$ & 27 & $2(1,3)$ & & \\
\hline
\end{tabular}

${ }^{\mathrm{a} K r u s k a l}$ Wallis test $\quad{ }^{*} \mathrm{p}<0.05 \quad{ }^{*} \mathrm{*}<0.01 \quad$ Q1: First quarter, Q3: Third Quarter

It is significantly different according to receiving benefit from advertising services according to the age of the entrepreneur (p:0.043) in Table XII. The benefit level of entrepreneurs between 26 and 30 years old is higher than the ones between 31 and 35 years old (p:0.038). Also, it is significantly different in terms of getting benefit from advertising services according to the educational status of the entrepreneur (p: 0.007). The benefit level of entrepreneurs with pre-Bachelor's degrees is lower than the ones with Bachelor's degrees (p:0.014).

It is significantly different in terms of benefiting from networking services according to the educational status of the entrepreneur (p: 0.031) in Table XIII. The benefit level of entrepreneurs with Bachelor's degrees is higher than the ones with pre-Bachelor's degrees (p:0.014). Entrepreneurs with Bachelor degrees can achieve a similar network through their college friends or university professors. Therefore, they benefit less from networking support.

It is significantly different in terms of benefiting from investment/finance services according to the age of the entrepreneur (p:0.017) in Table XIV. The benefit level of entrepreneurs between 31 and 35 years old is lower than the ones between 26 and 30 years old (p:0.009). Younger entrepreneurs benefit more from the investment/finance support because they have less capital. Older entrepreneurs may have accumulated more funds until that time frame.
TABLE XIII. COMPARISON OF THE LEVEL OF RECEIVING BENEFIT FROM THE NETWORKING SERVICE TO THE DEVELOPMENT OF THE COMPANY ACCORDING TO THE DEMOGRAPHICS OF THE ENTREPRENEUR

\begin{tabular}{|l|l|l|l|l|l|}
\hline \multirow{2}{*}{ (n:125) } & \multirow{2}{*}{$\mathbf{n}$} & \begin{tabular}{l} 
Networking \\
\cline { 3 - 5 }
\end{tabular} & $\begin{array}{l}\text { Median (Q1, } \\
\text { Q3) }\end{array}$ & value & p \\
\hline \multirow{3}{*}{$\begin{array}{l}\text { Educational } \\
\text { Status }\end{array}$} & $\begin{array}{l}\text { Pre- } \\
\text { Bachelor's }\end{array}$ & 16 & $3(3,4)$ & 6.956 & ${ }^{\mathrm{a}} 0.031^{*}$ \\
\cline { 2 - 6 } & Bachelor's & 82 & $4(3,5)$ & & \\
\cline { 2 - 5 } & $\begin{array}{l}\text { Master's } \\
\text { and up }\end{array}$ & 27 & $3(2,4)$ & & \\
\hline
\end{tabular}

TABLE XIV. COMPARISON OF THE LEVEL OF RECEIVING BENEFIT FROM THE INVESTMENT/FINANCE SERVICE TO THE DEVELOPMENT OF THE COMPANY ACCORDING TO THE DEMOGRAPHICS OF THE ENTREPRENEUR

\begin{tabular}{|c|c|c|c|c|c|}
\hline \multirow{2}{*}{\multicolumn{2}{|c|}{ (n:125) }} & \multirow{2}{*}{$\mathbf{n}$} & $\begin{array}{l}\text { Investment/ } \\
\text { Finance }\end{array}$ & \multirow{2}{*}{$\begin{array}{l}\text { Test } \\
\text { value }\end{array}$} & \multirow{2}{*}{$\mathbf{p}$} \\
\hline & & & $\begin{array}{l}\text { Median (Q1, } \\
\text { Q3) }\end{array}$ & & \\
\hline \multirow{4}{*}{ Age } & $<25$ & 40 & $3(1,4)$ & 10.132 & ${ }^{\mathrm{a}} 0.017 *$ \\
\hline & $26-30$ & 42 & $3.5(2,5)$ & & \\
\hline & 31-35 & 27 & $2(0,3)$ & & \\
\hline & $>35$ & 16 & $3(1.5,4)$ & & \\
\hline
\end{tabular}

TABLE XV. COMPARISON OF THE LEVEL OF RECEIVING BENEFIT FROM THE MEETING WITH INVESTORS SERVICE TO THE DEVELOPMENT OF THE COMPANY ACCORDING TO THE DEMOGRAPHICS OF THE ENTREPRENEUR

\begin{tabular}{|c|c|c|c|c|c|}
\hline \multirow{2}{*}{\multicolumn{2}{|c|}{ (n:125) }} & \multirow{3}{*}{$\begin{array}{l}\mathbf{n} \\
86\end{array}$} & $\begin{array}{l}\text { Meeting with } \\
\text { Investors }\end{array}$ & \multirow{3}{*}{$\begin{array}{l}\begin{array}{l}\text { Test } \\
\text { value }\end{array} \\
-2.401\end{array}$} & \multirow{3}{*}{$\begin{array}{l}\mathbf{p} \\
{ }^{\mathrm{b}} 0.016^{*}\end{array}$} \\
\hline & & & $\begin{array}{l}\text { Median (Q1, } \\
\text { Q3) }\end{array}$ & & \\
\hline \multirow{2}{*}{$\begin{array}{l}\text { There is an } \\
\text { Entrepreneur in } \\
\text { the Family or } \\
\text { Social Circle }\end{array}$} & Yes & & $3(2,4)$ & & \\
\hline & No & 39 & $4(3,5)$ & & \\
\hline
\end{tabular}

It is significantly different according to getting benefit from meeting with investors services according to the social circle of the entrepreneur (p:0.016) in Table XV. The benefit level of entrepreneurs without an entrepreneur in their families or social circle is higher than the ones with entrepreneurs in their families or social circle. Entrepreneurs with other entrepreneurs in their families can reach investors through their families so they don't benefit from this support as much as the others.

There is statistically significant difference according to getting benefit from going abroad services according to the age (p:0.037) in Table XVI. The benefit level of entrepreneurs between 31 and 35 years old is lower than the ones between 26 and 30 years old (p:0.049). This result is somewhat different than the result in Table III. According to Table III, younger entrepreneurs utilize going abroad services more especially the ones aged below 25 but according to this table, entrepreneurs aged between 26 and 30 benefit from going abroad services the most. It can be concluded from this result that entrepreneurs need to gain some experience before going abroad. 
TABLE XVI. COMPARISON OF THE LEVEL OF RECEIVING BENEFIT FROM THE GOING ABROAD SERVICE TO THE DEVELOPMENT OF THE COMPANY ACCORDING TO THE DEMOGRAPHICS OF THE ENTREPRENEUR

\begin{tabular}{|c|c|c|c|c|c|}
\hline \multirow{2}{*}{\multicolumn{2}{|c|}{ (n:125) }} & \multirow{3}{*}{$\begin{array}{l}\text { n } \\
40\end{array}$} & \multirow{3}{*}{$\begin{array}{l}\begin{array}{l}\text { Going } \\
\text { Abroad }\end{array} \\
\begin{array}{l}\text { Median } \\
(\mathbf{Q} 1, \mathbf{Q 3})\end{array} \\
1.5(0,4) \\
\end{array}$} & \multirow{3}{*}{$\begin{array}{l}\begin{array}{l}\text { Test } \\
\text { value }\end{array} \\
8.463\end{array}$} & \multirow{3}{*}{$\begin{array}{l}\mathbf{p} \\
{ }^{\mathrm{a}} 0.037^{*}\end{array}$} \\
\hline & & & & & \\
\hline \multirow{4}{*}{ Age } & $<25$ & & & & \\
\hline & $\begin{array}{l}26- \\
30\end{array}$ & 42 & $2(0,4)$ & & \\
\hline & $\begin{array}{l}31- \\
35\end{array}$ & 27 & $0(0,2)$ & & \\
\hline & $>35$ & 16 & $2.5(0.5,4)$ & & \\
\hline \multirow{2}{*}{$\begin{array}{l}\text { There is an } \\
\text { Entrepreneur in the } \\
\text { Family or Social Circle }\end{array}$} & Yes & 86 & $1(0,3)$ & -1.984 & b0.047* \\
\hline & No & 39 & $3(1,4)$ & & \\
\hline
\end{tabular}

According to the social circle of the entrepreneur, it is significantly different according to getting benefit from going abroad services (p:0.047) in Table XVI. The benefit level of entrepreneurs without an entrepreneur in their families or social circle is higher than the ones with entrepreneurs in their families or social circle. Entrepreneurs with families as entrepreneurs have usually a wider network and more opportunities compared to other entrepreneurs. Therefore, they have more to lose, if they go abroad. For this reason, they don't benefit as much from this service.

It is significantly different according to receiving benefit from patent application, legal counseling services and trademark registration ( $\mathrm{p}: 0.045)$ according to the age of the entrepreneur in Table XVII. The benefit level of entrepreneurs between 31 and 35 years old is lower than the ones younger than 25 years old (p:0.049). Older entrepreneurs may have more experience in this subject compared to younger ones and therefore, they benefit less.

It is significantly different according to getting benefit from patent application, legal counseling services and trademark registration (p: 0.007) according to the educational background of the entrepreneur in Table XVII. The benefit level of entrepreneurs with Bachelor's degrees is higher than the ones with Master's degrees and up (p:0.007). More educated entrepreneurs may have previously learned about this subject or taken classes/seminars related to the topic and therefore, need less help compared to less educated entrepreneurs.

It is significantly different according to receiving benefit from collaborating with organizations that support the accelerator according to the educational background of entrepreneurs (p: 0.004) in Table XVIII. The benefit level of entrepreneurs with Master's degrees and up is lower than the ones with Bachelor's degrees (p:0.004).

It is significantly different according to receiving benefit from technical support according to the educational status of entrepreneurs (p: 0.037) in Table XIX. The benefit level of entrepreneurs with Master's degrees and up is lower than the ones with Bachelor's degrees (p:0.049). The reason of this is because entrepreneurs with higher degrees probably took technical classes in schools and already know the subjects or they can learn these subjects by themselves through researching.

TABLE XVII. COMPARISON OF THE LEVEL OF RECEIVING BENEFIT FROM THE TRADEMARK REGISTRATION / PATENT APPLICATION / LEGAL COUNSELING SERVICES TO THE DEVELOPMENT OF THE COMPANY ACCORDING TO THE DEMOGRAPHICS OF THE ENTREPRENEUR

\begin{tabular}{|l|l|l|l|l|l|}
\hline \multirow{2}{*}{ (n:125) } & \multirow{2}{*}{$\mathbf{n}$} & $\begin{array}{l}\text { Trademark } \\
\text { Registration }\end{array}$ & \multirow{2}{*}{$\begin{array}{l}\text { Test } \\
\text { vedian (Q1, } \\
\text { Q3) }\end{array}$} & \multirow{2}{*}{$\mathbf{p}$} \\
\hline \multirow{4}{*}{ Age } & $<25$ & 40 & $3(1,4)$ & 8.058 & ${ }^{\mathrm{a}} 0.045^{*}$ \\
\cline { 2 - 7 } & $26-30$ & 42 & $2(1,4)$ & & \\
\cline { 2 - 7 } & $31-35$ & 27 & $1(0,3)$ & & \\
\cline { 2 - 7 } & $>35$ & 16 & $1(0,3.5)$ & & \\
\hline \multirow{4}{*}{$\begin{array}{l}\text { Educational } \\
\text { Status }\end{array}$} & $\begin{array}{l}\text { Pre- } \\
\text { Bachelor's }\end{array}$ & 16 & $1.5(0,3)$ & 10.051 & ${ }^{\mathrm{a}} 0.007^{* *}$ \\
\cline { 2 - 7 } & Bachelor's & 82 & $3(1,4)$ & & \\
\cline { 2 - 7 } & $\begin{array}{l}\text { Master's } \\
\text { and up }\end{array}$ & 27 & $1(0,2)$ & & \\
\hline
\end{tabular}

TABLE XVIII.COMPARISON OF THE LEVEL OF RECEIVING BENEFIT FROM THE COLLABORATING WITH ORGANIZATIONS THAT SUPPORT THE ACCELERATOR SERVICES TO THE DEVELOPMENT OF THE COMPANY ACCORDING TO THE DEMOGRAPHICS OF THE ENTREPRENEUR

\begin{tabular}{|c|c|c|c|c|c|}
\hline \multirow{2}{*}{\multicolumn{2}{|c|}{ (n:125) }} & \multirow[t]{2}{*}{$\mathbf{n}$} & $\begin{array}{l}\text { Collaborating } \\
\text { with } \\
\text { Organizations }\end{array}$ & \multirow{2}{*}{$\begin{array}{l}\text { Test } \\
\text { value }\end{array}$} & \multirow{2}{*}{$\mathbf{p}$} \\
\hline & & & $\begin{array}{l}\text { Median (Q1, } \\
\text { Q3) }\end{array}$ & & \\
\hline \multirow{3}{*}{$\begin{array}{l}\text { Educational } \\
\text { Status }\end{array}$} & $\begin{array}{l}\text { Pre- } \\
\text { Bachelor's }\end{array}$ & 16 & $2.5(1,4)$ & 10.927 & ${ }^{\mathrm{a}} 0.004 * *$ \\
\hline & Bachelor's & 82 & $4(2,4)$ & & \\
\hline & $\begin{array}{l}\text { Master's } \\
\text { and up }\end{array}$ & 27 & $2(0,3)$ & & \\
\hline
\end{tabular}

TABLE XIX. COMPARISON OF THE LEVEL OF RECEIVING BENEFIT FROM THE TECHNICAL SUPPORT SERVICES TO THE DEVELOPMENT OF THE COMPANY ACCORDING TO THE DEMOGRAPHICS OF THE ENTREPRENEUR

\begin{tabular}{|c|c|c|c|c|c|}
\hline \multirow{2}{*}{ (n:125) } & & \multirow{2}{*}{$\mathbf{n}$} & $\begin{array}{l}\text { Technical } \\
\text { Support }\end{array}$ & \multirow{2}{*}{$\begin{array}{l}\text { Test } \\
\text { value }\end{array}$} & \multirow{2}{*}{$\mathbf{p}$} \\
\hline & & & $\begin{array}{l}\text { Medyan } \\
(\text { Q1, Q3) }\end{array}$ & & \\
\hline \multirow{3}{*}{$\begin{array}{l}\text { Educational } \\
\text { Status }\end{array}$} & $\begin{array}{l}\text { Pre- } \\
\text { Bachelor's }\end{array}$ & 16 & $1(0,3.5)$ & 6.590 & ${ }^{\mathrm{a}} 0.037 *$ \\
\hline & Bachelor's & 82 & $2.5(1,4)$ & & \\
\hline & $\begin{array}{l}\text { Master's } \\
\text { and up }\end{array}$ & 27 & $1(0,2)$ & & \\
\hline
\end{tabular}

According to the above analyses and results seen from Table VIII to Table XIX, in terms of getting benefit from the accelerator supports between men and women, no statistically significant difference exists. In relation to the age of entrepreneurs, it is significantly different according to receiving benefit from mentoring, laboratory, advertising, finance/investment, going abroad and trademark registration 
services. In relation to the educational status of entrepreneurs, significant difference is found in terms of getting benefit from training, office, advertising, networking, trademark registration, collaborating with other organizations and technical supports. In relation to the previous professional work experience of entrepreneurs, no statistically significant difference is found according to receiving benefit from the accelerator supports. In relation to the previous entrepreneurship experience of entrepreneurs, it is significantly different according to getting benefit from the accelerator supports. In relation to having an entrepreneur within the close family or social circle, statistically difference is found according to getting benefit from training, mentorship, meeting with investors and going abroad supports.

\section{B. Regression Models}

1) Research of accelerator support utilization according to entrepreneurship data: GLMM (generalized linear mixed models) are used to evaluate the effects of data on support utilization levels of entrepreneurs. Factors affecting each support are evaluated individually in univariate analyses. In models, it is aimed to study the effects of multiple factors on utilization levels together. While supports are included as dependent variables in the models, factors that are found to have statistically significant $(p<0.05)$ effects in univariate analyses are included as independent variables.

In univariate analyses, none of the demographic factors is found statistically significant on entrepreneurs' utilization level of training, mentorship, laboratory, advertisement, networking, investment/finance, meeting with investors supports. For this reason, no model has been created for these variables. Models are only created for the variables that produced more than one significant result $(\mathrm{p}<0.05)$ in univariate analyses.

a) Office Support: In the univariate analyses, the effects of age and having an entrepreneur in the family are found to be statistically significant on entrepreneurs' utilization level of office support. As it can be seen in Table XX, it is found that the model in which these two variables are included as independent variables is statistically significant (F: 3.555, p: 0.009). In the model, age and to have an entrepreneur in the family are found to be statistically significant (p: 0.026, p: 0.045 , correspondingly). When pairwise comparisons for age variable are examined, it is found that the utilization levels of the entrepreneurs under 25 years old are higher than the utilization levels of the entrepreneurs who are between the ages of 31 and 35 and over 35 years old (p: 0.032, p: 0.014, correspondingly). It is also found that the utilization levels of the entrepreneurs between the ages of 26 and 30 are higher than the utilization levels of the entrepreneurs who are over 35 years old (p: 0.048).

b) In univariate analyses, the effects of age and having professional work experience of entrepreneurs are found to be statistically significant on the level of utilizing going abroad services. As it can be seen in Table XXI, it is found that the model in which these two variables are included as independent variables is statistically significant (F: 3.812, p: 0.001). In the model, age and having professional work experience are found to be statistically significant (p: 0.034, p: 0.036 , correspondingly). When pairwise comparisons for age variable are examined, it is found that the utilization levels of the entrepreneurs between the ages of 31 and 35 are lower than the utilization levels of entrepreneurs who are under 25 years old and between the ages of 26 and 30 (p: 0.006, p: 0.011, correspondingly).

According to Table XXI, when the pairwise comparisons for having professional work experience are examined, it is found that the utilization levels of the entrepreneurs with 1-2 years of experience are higher than the utilization levels of entrepreneurs with 3-5 years and 6-7 years of experience (correspondingly, p: 0.045, p: 0.008). The utility levels of entrepreneurs with 8 years or more professional work experience are found to be higher than those of entrepreneurs with 6 to 7 years of experience (p: 0.044).

TABLE XX. The Model Created to Determine the Factors that AFFECT THE LEVEL OF OFFICE USE

\begin{tabular}{|l|l|l|l|l|}
\hline & Beta & t & p & $\begin{array}{l}\text { 95\% } \\
\text { Confidence } \\
\text { Interval for } \\
\text { Beta }\end{array}$ \\
\hline Constant (Intercept) & 3.485 & 9.313 & $<0.001^{* *}$ & $2.744,4.226$ \\
\hline Age (<25) & 0.971 & 2.498 & $0.014^{*}$ & $0.201,1.740$ \\
\hline Age (26-30) & 0.802 & 1.993 & $0.048^{*}$ & $0.005,1.598$ \\
\hline Age (31-35) & 0.378 & 0.856 & 0.394 & $-0.496,1.251$ \\
\hline Age (>35) & - & - & - & - \\
\hline $\begin{array}{l}\text { Have an entrepreneur } \\
\text { in the family or not } \\
\text { (Have) }\end{array}$ & 0.470 & 2.021 & $0.045^{*}$ & $0.010,0.930$ \\
\hline
\end{tabular}

TABLE XXI. The Model CREATED TO DETERmine THE FACtors THAT AFFECT THE LEVEL OF GOING ABROAD UTILIZATION

\begin{tabular}{|c|c|c|c|c|}
\hline & Beta & $\mathbf{t}$ & $\mathbf{p}$ & $\begin{array}{l}95 \% \\
\text { Confidence } \\
\text { Interval for } \\
\text { Beta }\end{array}$ \\
\hline Constant (Intercept) & 1.625 & 4.124 & $<0.001^{* *}$ & $0.845,2.405$ \\
\hline Age $(<25)$ & - & - & - & - \\
\hline Age (26-30) & -0.212 & -0.546 & 0.586 & $-0.981,0.556$ \\
\hline Age (31-35) & -1.323 & -2.798 & $0.006^{* *}$ & $\begin{array}{l}-2.259,- \\
0.386\end{array}$ \\
\hline Age (>35) & -1.068 & -1.595 & 0.113 & $-2.395,0.258$ \\
\hline $\begin{array}{l}\text { Have professional work } \\
\text { experience (None) }\end{array}$ & -0.023 & -0.032 & 0.974 & $-1.419,1.374$ \\
\hline $\begin{array}{l}\text { Have professional work } \\
\text { experience (1-2 years) }\end{array}$ & 0.250 & 0.455 & 0.650 & $-0.840,1.341$ \\
\hline $\begin{array}{l}\text { Have professional work } \\
\text { experience (3-5 years) }\end{array}$ & -0.665 & -1.289 & 0.200 & $-1.688,0.357$ \\
\hline $\begin{array}{l}\text { Have professional work } \\
\text { experience (6-7 years) }\end{array}$ & -1.090 & -2.035 & $0.044 *$ & $\begin{array}{l}-2.150,- \\
0.029\end{array}$ \\
\hline $\begin{array}{l}\text { Have professional work } \\
\text { experience (8 years and } \\
\text { above) }\end{array}$ & - & - & - & - \\
\hline
\end{tabular}


c) Trademark registration / Patent application / Legal Counseling Support: In the univariate analyses, the effects of age and educational status of entrepreneurs are found to be statistically significant on the level of utilizing trademark registration / patent application / legal counseling services. As it can be seen in Table XXII, the model in which these two variables are included as independent variables is found to be statistically significant (F: 5.230, $p<0.001$ ). The effect of the educational status in the model is found to be statistically significant (p: 0.022). However, the effect of age is found to be statistically insignificant (p: 0.320). When pairwise comparisons of educational status are examined, it is found that the utilization levels of entrepreneurs with a bachelor's degree are higher than those of entrepreneurs with a graduate degree (p: 0.006).

d) Collaborating with organizations that support the accelerator: In univariate analyses, the effects of age and educational status of entrepreneurs are found to be statistically significant on the level of entrepreneurs' ability to cooperate with supporting organizations. The model in which these two variables are included as independent variables is found to be statistically significant (F: 5.230, p <0.001). Although the model was meaningful, the effects of age or educational status on the model are not found to be statistically significant (p: 0.128, p: 0.173, correspondingly).

e) Technical Support: In the univariate analyses, the effects of age and educational status of entrepreneurs are found to be statistically significant on the levels of utilizing technical support. As can be seen in Table XXIII, the model in which these two variables are included as independent variables is found to be statistically significant (F: 4.697, p: 0.001). In the model, the effects of age and educational status were statistically significant (p: 0.008, p: 0.024 , correspondingly).

According to Table XXIII, when the pairwise comparisons for age variable are examined, the utilization levels of the entrepreneurs between the ages of 26 and 30 are found to be lower than the utilization levels of entrepreneurs under 25, between 31 and 35 and over 35 years old (p: 0.028, p: 0.003, $\mathrm{p}$ : 0.033). When pairwise comparisons of entrepreneurs' educational status are examined, it is found that the utilization levels of entrepreneurs with a bachelor's degree are higher than those of entrepreneurs with a graduate degree (p: 0.006).

2) Research of the benefit levels of accelerator supports according to entrepreneurship data: GLMM (generalized linear mixed models) are used to evaluate the effects of data on the level of receiving benefit for company development from the supports of accelerator programs. Factors affecting each support are evaluated individually in univariate analyses. In models, it is aimed to study the effects of multiple factors on benefit levels together. While supports are included as dependent variables in the models, factors that are found to have statistically significant $(p<0.05)$ effects in univariate analyses are included as independent variables.
TABLE XXII. THE MODEL CREATED TO DETERMINE THE FACTORS THAT AFFECT THE LEVEL OF TRADEMARK REGISTRATION / PATENT APPLICATION / LEGAL COUNSELING UTILIZATION

\begin{tabular}{|l|l|l|l|l|}
\hline & Beta & $\mathbf{t}$ & $\mathbf{p}$ & $\begin{array}{l}\mathbf{9 5 \%} \\
\text { Confidence } \\
\text { Interval for } \\
\text { Beta }\end{array}$ \\
\hline Constant (Intercept) & 1.177 & 2.830 & $0.005^{* *}$ & $0.353,2.000$ \\
\hline Age (<25) & 0.790 & 1.439 & 0.153 & $-0.297,1.876$ \\
\hline Age (26-30) & 0.400 & 0.781 & 0.436 & $-0.613,1.412$ \\
\hline Age (31-35) & 0.086 & 0.164 & 0.870 & $-0.948,1.120$ \\
\hline Age (>35) & - & - & - & - \\
\hline $\begin{array}{l}\text { Education (Before } \\
\text { Bachelor's) }\end{array}$ & 0.745 & 1.580 & 0.117 & $-0.189,1.679$ \\
\hline Education (Bachelor's) & 0.919 & 2.809 & $0.006^{* *}$ & $0.271,1.566$ \\
\hline Education (Graduate) & - & - & - & - \\
\hline
\end{tabular}

TABLE XXIII.THE MODEL CREATED TO DETERMINE THE FACTORS THAT AFFECT THE LEVEL OF TECHNICAL SUPPORT UTILIZATION

\begin{tabular}{|l|l|l|l|l|}
\hline & Beta & $\mathbf{t}$ & $\mathbf{p}$ & $\begin{array}{l}\text { 95\% } \\
\text { Confidence } \\
\text { Interval for } \\
\text { Beta }\end{array}$ \\
\hline Constant (Intercept) & 1.198 & 2.619 & $0.010^{*}$ & $0.292,2.104$ \\
\hline Age (<25) & 0.279 & 0.504 & 0.615 & $-0.817,1.375$ \\
\hline Age (26-30) & 1.084 & 2.162 & $0.033^{*}$ & $0.091,2.076$ \\
\hline Age (31-35) & 0.051 & 0.097 & 0.923 & $-0.978,1.079$ \\
\hline Age (>35) & - & - & - & - \\
\hline $\begin{array}{l}\text { Education (Before } \\
\text { Bachelor's) }\end{array}$ & 0.747 & 1.444 & 0.151 & $-0.277,1.771$ \\
\hline Education (Bachelor's) & 0.869 & 2.775 & $0.006 * *$ & $0.249,1.489$ \\
\hline Education (Graduate) & - & - & - & - \\
\hline
\end{tabular}

In univariate analyses, only educational status is found statistically significant on the level of receiving benefit for company development from the office, networking, collaborating with organizations and technical supports. Only age is found statistically significant on the laboratory and investment/finance supports. Only having an entrepreneur in the family is found statistically significant on meeting with investors supports. For this reason, no model has been created for these variables. Models are only created for the variables that produced more than one significant result $(\mathrm{p}<0.05)$ in univariate analyses.

a) Training Support: In univariate analyses, the effects of educational status and to have an entrepreneur in the family are found to be statistically significant on the level of receiving benefit for company development from the training support. As it can be seen in Table XXIV, the model in which these two variables are included as independent variables is found to be statistically significant (F: 4.722, p: 0.005). While the effect of the educational status in the model was significant, it is found that the effect of having an entrepreneur in the family is meaningless (p: 0.006, p: 0.156, 
correspondingly). When the pairwise comparisons of educational status are examined, it is found that the level of receiving benefit for company development by the training support is higher in entrepreneurs who have Pre-Bachelor's degrees compared to entrepreneurs with Bachelor's degrees and graduate degrees. (p: 0.038, p: 0.001, correspondingly). Similarly, entrepreneurs with Bachelor's degrees are found to receive more benefits for their companies via the training support compared to entrepreneurs with graduate degrees. (p: 0.049).

b) Mentorship Support: In the univariate analyses, the effects of age and to have an entrepreneur in the family are found to be statistically significant on the level of receiving benefit for company development from the mentorship support. As it can be seen in Table XXV, the model in which these two variables are included as independent variables was determined to be statistically significant (F: 5.075, p: 0.001). In the model, the effects of age and having an entrepreneur in the family are found to be statistically significant (p: 0.007, p: 0.005 , correspondingly). When the pairwise comparisons of age are examined, it is found that the level of receiving benefit by the mentoring support for the company development is higher in entrepreneurs who are between the ages of 26 and 30 than the level of entrepreneurs who are between the ages of 31 and 35 and over 35 (p: 0.002, p: 0048). Similarly, in entrepreneurs whose age is below 25 years old, it is found that the level of receiving benefit by the mentoring support for the company development is higher than the entrepreneurs between the ages of 31 and 35 (p: 0.026). Also, it is found that the level of receiving benefit by the mentoring support is higher in entrepreneurs without an entrepreneur in their families compared to the ones who have an entrepreneur in their families (p: 0.005).

c) Advertising Support: In the univariate analyses, the effects of age and educational status are found to be statistically significant on the level of receiving benefit for company development from the advertising support. As it can be seen in Table XXVI, the model in which these two variables are included as independent variables is found to be statistically significant (F: 4.585, p: 0.001). In the model, the effects of age and educational status are statistically significant (p: 0.049, p: 0.021, correspondingly). When agerelated pairwise comparisons are examined, it is found that the level of receiving benefit by the advertising support for the company development is lower in entrepreneurs who are between the ages of 31 and 35 than the level of entrepreneurs who are under the age of 25 and between the ages of 26 and 30 (p: 0.045, p: 0.010, correspondingly). When pairwise comparisons of educational status are examined, it is found that the level of receiving benefit from advertising support for company development is higher in entrepreneurs who have bachelor's degrees than the level of entrepreneurs with PreBachelor's degrees. (p: 0.007).
TABLE XXIV. THE Model CReAted to Determine the Factors THAT AFFECT THE LEVEL OF RECEIVING BENEFIT FOR COMPANY DEVELOPMENT BY TRAINING SUPPORT

\begin{tabular}{|l|l|l|l|l|}
\hline & Beta & $\mathbf{t}$ & $\mathbf{p}$ & $\begin{array}{l}\mathbf{9 5 \%} \\
\text { Confidence } \\
\text { Interval for } \\
\text { Beta }\end{array}$ \\
\hline Constant (Intercept) & 1.499 & 22.557 & $<0.001^{* *}$ & $1.363,1.636$ \\
\hline $\begin{array}{l}\text { Education (Before } \\
\text { Bachelor's) }\end{array}$ & - & - & - & - \\
\hline Education (Bachelor's) & -0.143 & -2.273 & $0.032^{*}$ & $\begin{array}{l}-0.272,- \\
0.013\end{array}$ \\
\hline Education (Graduate) & -0.308 & -3.193 & $0.002^{* *}$ & $\begin{array}{l}-0.500,- \\
0.116\end{array}$ \\
\hline $\begin{array}{l}\text { Have an entrepreneur } \\
\text { in the family or not } \\
\text { (Have) }\end{array}$ & -0.089 & -1.429 & 0.156 & $-0.213,0.035$ \\
\hline
\end{tabular}

TABLE XXV. THE MODEl CREATED to DETERMINE THE FACTORS THAT AFFECT THE LEVEL OF RECEIVING BENEFIT FOR COMPANY DEVELOPMENT BY MENTORSHIP SUPPORT

\begin{tabular}{|c|c|c|c|c|}
\hline & Beta & $\mathbf{t}$ & $\mathbf{p}$ & $\begin{array}{l}95 \% \\
\text { Confidence } \\
\text { Interval for } \\
\text { Beta }\end{array}$ \\
\hline Constant (Intercept) & 4.449 & 22.159 & $<0.001^{* *}$ & 4.046, 4.852 \\
\hline Age $(<25)$ & - & - & - & - \\
\hline Age (26-30) & 0.141 & 0.646 & 0.521 & $-0.294,0.576$ \\
\hline Age (31-35) & -0.673 & -2.261 & $0.026^{*}$ & $\begin{array}{l}-1.263,- \\
0.084\end{array}$ \\
\hline Age (>35) & -0.613 & -1.498 & 0.137 & $-1.423,0.197$ \\
\hline $\begin{array}{l}\text { Have an entrepreneur } \\
\text { in the family or not } \\
\text { (Have) }\end{array}$ & -0.547 & -2.933 & $0.005^{* *}$ & $\begin{array}{l}-0.920,- \\
0.174\end{array}$ \\
\hline
\end{tabular}

TABLE XXVI. THE Model CREATED to Determine the Factors THAT AFFECT THE LEVEL OF RECEIVING BENEFIT FOR COMPANY DEVELOPMENT BY ADVERTISING SUPPORT

\begin{tabular}{|l|l|l|l|l|}
\hline & Beta & $\mathbf{t}$ & $\mathbf{p}$ & $\begin{array}{l}\mathbf{9 5 \%} \\
\text { Confidence } \\
\text { Interval for } \\
\text { Beta }\end{array}$ \\
\hline Constant (Intercept) & 1.684 & 4.422 & $<0.001^{* *}$ & $0.926,2.443$ \\
\hline Age (<25) & - & - & - & - \\
\hline Age (26-30) & 0.197 & 0.509 & 0.612 & $-0.570,0.965$ \\
\hline Age (31-35) & -0.742 & -2.042 & $0.045^{*}$ & $\begin{array}{l}-1.467,- \\
0.017\end{array}$ \\
\hline Age (>35) & -0.375 & -0.713 & 0.477 & $-1.415,0.666$ \\
\hline $\begin{array}{l}\text { Education (Before } \\
\text { Bachelor's) }\end{array}$ & - & - & - & - \\
\hline Education (Bachelor's) & 1.179 & 2.756 & $0.007^{* *}$ & $0.330,2.027$ \\
\hline Education (Graduate) & 0.725 & 1.535 & 0.129 & $-0.216,1.665$ \\
\hline
\end{tabular}


d) Going Abroad Support: In the univariate analyses, the effects of age and to have an entrepreneur in the family are found to be statistically significant on the level of receiving benefit for company development from the going abroad support. As can be seen in Table XXVII, the model in which these two variables are included as independent variables was found to be statistically significant (F: 4.270, p: 0.003). While the effect of the age variable is statistically significant in the model, it is found that the effect of having an entrepreneur in the family is meaningless (p: 0.015, p: 0.087, correspondingly). When age-related pairwise comparisons are examined, it is found that the level of receiving benefit by the going abroad support for the company development is higher in entrepreneurs who are between 31 and 35 years old compared to ones under 25, between 26 and 30 and over 35 years old (p: 0.012, p: 0.005, p:0.041, correspondingly).

e) Trademark registration / Patent application / Legal Counseling Support: In the univariate analysis, the effects of age and educational status are found to be statistically significant on the level of receiving benefit for company development from the trademark registration / patent application / legal counseling support. As can be seen in Table XXVIII, the model in which these two variables are included as independent variables was found to be statistically significant (F: 4.585, p: 0.001). While the effect of educational status on the model is found to be statistically significant, the effect of age is found to be insignificant (p: 0.017, p: 0.183, correspondingly). When the pairwise comparisons of educational status are examined, it is found that the level of receiving benefit by the trademark registration / patent application / legal counseling support for the company development is higher in entrepreneurs who have Bachelor's degrees compared to the ones who have graduate degrees ( $\mathrm{p}$ : $0.008)$.

TABLE XXVII. THE Model CREATED to Determine the Factors THAT AFFECT THE LEVEL OF RECEIVING BENEFIT FOR COMPANY DEVELOPMENT BY GOING ABROAD SUPPORT

\begin{tabular}{|l|l|l|l|l|}
\hline & Beta & $\mathbf{t}$ & $\mathbf{p}$ & $\begin{array}{l}\text { 95\% } \\
\text { Confidence } \\
\text { Interval for } \\
\text { Beta }\end{array}$ \\
\hline Constant (Intercept) & 2.587 & 6.100 & $<0.001^{* *}$ & $1.747,3.426$ \\
\hline Age (<25) & - & - & - & - \\
\hline Age (26-30) & 0.127 & 0.293 & 0.770 & $-0.729,0.983$ \\
\hline Age (31-35) & -1.084 & -2.578 & $0.012^{*}$ & $\begin{array}{l}-1.922,- \\
0.247\end{array}$ \\
\hline Age (>35) & 0.102 & 0.175 & 0.862 & $-1.057,1.262$ \\
\hline $\begin{array}{l}\text { Have an entrepreneur } \\
\text { in the family or not } \\
\text { (Have) }\end{array}$ & -0.628 & -1.728 & 0.087 & $-1.347,0.092$ \\
\hline
\end{tabular}

$* \mathrm{p}<0.05 \quad * * \mathrm{p}<0.01$
TABLE XXVIII. THE MODEL CREATED to DETERMINE THE FACTORS THAT AFFECT THE LEVEL OF RECEIVING BENEFIT FOR COMPANY DEVELOPMENT BY TRADEMARK REGISTRATION / PATENT APPLICATION / LEGAL COUNSELING

\begin{tabular}{|l|l|l|l|l|}
\hline & Beta & $\mathbf{t}$ & $\mathbf{p}$ & $\begin{array}{l}\text { 95\% } \\
\text { Confidence } \\
\text { Interval for } \\
\text { Beta }\end{array}$ \\
\hline Constant (Intercept) & 1.367 & 3.057 & $0.003 * *$ & $0.480,2.255$ \\
\hline Age (<25) & 0.591 & 1.018 & 0.311 & $-0.559,1.741$ \\
\hline Age (26-30) & 0.158 & 0.286 & 0.775 & $-0.933,1.249$ \\
\hline Age (31-35) & -0.320 & -0.588 & 0.557 & $-1.399,0.758$ \\
\hline Age (>35) & - & - & - & - \\
\hline $\begin{array}{l}\text { Education (Before } \\
\text { Bachelor's) }\end{array}$ & 0.235 & 0.408 & 0.684 & $-0.908,1.379$ \\
\hline Education (Bachelor's) & 0.984 & 2.720 & $0.008 * *$ & $0.263,1.705$ \\
\hline Education (Graduate) & - & - & - & - \\
\hline
\end{tabular}

\section{DisCUSSION}

This research performs a statistical analysis on entrepreneurs' usage of supports provided by the accelerator programs in relation to their demographics. It is studied whether entrepreneurs' gender, age, educational status, work experience and family background affect the need of receiving support from the accelerator program. According to entrepreneurs' backgrounds, it has also been researched which entrepreneurs use and benefit from which services the most. In order to find out this, several statistical analysis and a regression model has been performed in this research and performed to the entrepreneurs in the chosen accelerator programs located in Istanbul, Turkey.

Ratinho [19] made a research with Business Incubators in Europe and investigated how much help tenant companies receive from the incubator to solve their business problems. Incubators don't help the tenant companies to solve all of their problems and can only help solving half of them. Also, he investigated the companies' support seeking habits from the perspective of company age, size and human capital. This study looks at startups' support utilization levels and how much benefit they receive from these supports from the perspective of entrepreneurs' demographics instead of the firms' perspective. It tries to identify which supports/services startups use the most according to entrepreneurs' gender, age, educational status, work experience and family background.

A key finding from this research is that there is no relation with gender in terms of entrepreneurs' usage and getting benefit from the accelerator supports. This finding is similar to Schipper's study on gender [60]. Schipper, et al. [60] made a study with 703 first year college students at Rotterdam School of Management and they evaluated the effects of a brief, evidence-based online interference. According to this study, the gap in accomplishments between men and women became considerably smaller within the intervention cohort. After Year 1, the gender gap closed by $98 \%$ meaning that gender doesn't have any impact on academic achievement. 
Other key findings from this study is that age and educational background of the entrepreneur affect the most on entrepreneurs' usage and getting benefit from the accelerator supports. As age and the educational status grows, entrepreneurs' need of receiving support and benefiting from these supports decrease. As people get older, they acquire more experiences. Moreover, when they receive more education, they obtain more knowledge. Therefore, older and more educated entrepreneurs receive less support from the accelerator program compared to younger and less educated ones. It is also found out that entrepreneur's family background has a big effect on receiving and benefiting from the supports of the accelerator. Although Hallen, et al. [61] did not find any statistically significant difference on the benefit level of entrepreneurs who have previous entrepreneurship related experience. In this study, it has found that entrepreneurs with entrepreneurs in their close families need less support from the accelerator because they use their families' resources. The reason of this difference may be due to the cultural factors. The study of Hallen, et al. [61] is based on two accelerators located in the US where there is an individualistic culture. On the other hand, this research is based on accelerators located in Istanbul, Turkey where there is a collectivistic culture according to Hofstede Insights [62].

\section{CONCLUSION}

This research adds to the nascent literature on accelerators by making an empirical study on entrepreneurs currently participating or previously participated to accelerator programs. The current literature about accelerators mainly researches the processes and business models of the programs in addition to incubators. The literature is lacking a study on accelerator programs and how entrepreneurs attending these programs utilize their services or how much benefit they receive from these programs. If accelerator programs consider the findings in this study, they can enhance their programs. Thus, they can modify the services they provide in relation to the entrepreneurs' requests and can add more to their development. Therefore, as more entrepreneurs and startups become successful, they can contribute more to the economy of their region. Technology initiatives, which are established with low capital and produce high value-added products and services, play a key role in furthering the economies of emerging countries such as Turkey.

There are limitations in this study. First, this study doesn't involve accelerator programs in other countries and is only based on Istanbul, Turkey. Second, it includes entrepreneurs presently participating in the accelerator programs and who graduated recently within the past two years of the programs due to the difficulty of connecting with entrepreneurs who attended the programs more than two years ago. Third, causation is not checked in this study because in order to analyze causation, correlation analysis must be performed. Instead of correlation analysis, regression analysis is preferred in this study due to the fact that the study aims to identify the effect of one or more variables on another by presenting a model. Fourth, response bias should be considered between men and women since they are emotionally different, there may be psychological differences on how they respond to survey questions. Future studies can study entrepreneurs in other countries to explore their needs from the accelerator programs. Moreover, comparative analysis can be done between entrepreneurs attending other accelerator programs in different countries.

\section{REFERENCES}

[1] Clarysse, M. Wright and J. Van Hove, "A look inside accelerators", Nesta, London, UK, 2015.

[2] Y. Hochberg, "Accelerating Entrepreneurs and Ecosystems: The Seed Accelerator Model", Innovation Policy and the Economy, vol. 16, pp. 25-51, 2016.

[3] N. Dee, D. Gill, T. Livesey and T. Minshall, "Incubation for growth: A review of the impact of business incubation on new ventures with high growth potential.", NESTA, 2011.

[4] R. Smilor, "Managing the incubator system: Critical success factors to accelerate new company development", IEEE Transactions on Engineering Management, vol. -34, no. 3, pp. 146-155, 1987.

[5] D. Adkins, A brief history of business incubation in the United States. Athens, Ohio: National Business Incubation Association, 2002.

[6] R. Lalkaka and J. Bishop, Business incubators in economic development: an initial assessment in industrializing countries. New York, NY: United Nations Industrial Development Organization, 1996.

[7] J. Bruneel, T. Ratinho, B. Clarysse and A. Groen, "The Evolution of Business Incubators: Comparing demand and supply of business incubation services across different incubator generations", Technovation, vol. 32, no. 2, pp. 110-121, 2012.

[8] K. Goswami, J. Mitchell and S. Bhagavatula, "Accelerator expertise: Understanding the intermediary role of accelerators in the development of the Bangalore entrepreneurial ecosystem", Strategic Entrepreneurship Journal, vol. 12, no. 1, pp. 117-150, 2018.

[9] C. Cubukcu and S. Gulsecen, "Accelerator Programs in Turkey: Who Benefits the Most from These Programs?", in New Studies and Research in Economics, Rome, Italy: Euser, pp. 5-16, 2019.

[10] S. Cohen and Y. Hochberg, "Accelerating Startups: The Seed Accelerator Phenomenon", SSRN Electronic Journal, 2014.

[11] I. Ozkasikci, Dijital cagda girişimcilik ekosistemi [Entrepreneurship ecosystem in digital age], 1st ed. Istanbul: Butik Publishing, 2013.

[12] P. Miller and K. Bound, "The startup factories: The rise of accelerator programmes to support new ventures", Nesta, London, 2011.

[13] M. Marangoz, Girisimcilikte guncel konular ve uygulamalar [Current topics and applications in entrepreneurship], 1st ed. Istanbul: Inkilap Publishing, 2016.

[14] S. Mian, W. Lamine and A. Fayolle, "Technology Business Incubation: An overview of the state of knowledge", Technovation, vol. 50-51, pp. 1-12, 2016.

[15] J. Majava, T. Kinnunen, D. Foit and P. Kess, "An intermediary as a trust enabler in a spatial business ecosystem", International Journal of Innovation and Learning, vol. 20, no. 2, p. 199, 2016.

[16] B. Yin and J. Luo, "How Do Accelerators Select Startups? Shifting Decision Criteria Across Stages", IEEE Transactions on Engineering Management, vol. 65, no. 4, pp. 574-589, 2018.

[17] C. Pauwels, B. Clarysse, M. Wright and J. Van Hove, "Understanding a new generation incubation model: The accelerator", Technovation, vol. 50-51, pp. 13-24, 2016.

[18] C. Uhm, C. Sung and J. Park, "Understanding the accelerator from resources-based perspective", Asia Pacific Journal of Innovation and Entrepreneurship, vol. 12, no. 3, pp. 258-278, 2018.

[19] M. International Capital, Msci.com, 2019. [Online]. Available: https://www.msci.com/documents/10199/c0db0a48-01f2-4ba9-ad01226fd5678111. [Accessed: 21- Aug- 2019].

[20] Worldpopulationreview.com, 2019. [Online]. Available: http://worldpo pulationreview.com/countries/. [Accessed: 21- Aug- 2019].

[21] "Turkey: number of internet users 2019 | Statista", Statista, 2019. [Online]. Available: https://www.statista.com/statistics/369725/internetusers-turkey/. [Accessed: 21- Aug- 2019].

[22] "Turkey: smartphone user penetration 2015-2022 | Statista", Statista, 2019. [Online]. Available: https://www.statista.com/statistics/568281/ 
predicted-smartphone-user-penetration-rate-in-turkey/. [Accessed: 21Aug- 2019].

[23] G. Albort-Morant and P. Oghazi, "How useful are incubators for new entrepreneurs?", Journal of Business Research, vol. 69, no. 6, pp. 21252129, 2016.

[24] C. Battistella, A. De Toni and E. Pessot, "Open accelerators for start-ups success: a case study", European Journal of Innovation Management, vol. 20, no. 1, pp. 80-111, 2017. Available: 10.1108/ejim-10-2015-0113.

[25] T. Kohler, "Corporate accelerators: Building bridges between corporations and startups", Business Horizons, vol. 59, no. 3, pp. 347357, 2016.

[26] T. Ratinho, "Are They Helping? An Examination of Business Incubators' Impact on Tenant Firms", PhD, University of Twente, 2011.

[27] S. Hackett and D. Dilts, "A Systematic Review of Business Incubation Research", The Journal of Technology Transfer, vol. 29, no. 1, pp. 5582, 2004.

[28] C. Cubukcu and S. Gulsecen, "Accelerator programs in Turkey: From which services entrepreneurs benefit the most?", in Academic Studies in Social, Human and Administrative Sciences, IVPE, 2018, Editor: Hasan Babacan ve Marijan Premović, Page Number: 380, ISBN: 978-9940540-33-3.

[29] C. Cubukcu and S. Gulsecen, "Effectiveness of business accelerator services in Turkey: from the perspective of startups", International Journal of Innovation and Learning, vol. 26, no. 4, p. 426, 2019. Available: 10.1504/ijil.2019.10024011.

[30] H. Berglann, E. Moen, K. Røed and J. Skogstrøm, "Entrepreneurship: Origins and returns", Labour Economics, vol. 18, no. 2, pp. 180-193, 2011.

[31] "Infographic| Women Who Tech", Women Who Tech, 2019. [Online]. Available: https://www.womenwhotech.com/womenintechinfographic. [Accessed: 19- Nov- 2017].

[32] F. Cáceres-Carrasco and J. Guzmán-Cuevas, "Functional and productive dependence: new characteristics for the analysis of enterprises from a macroeconomic view", International Entrepreneurship and Management Journal, vol. 6, no. 2, pp. 117-130, 2010.

[33] D. Hechavarria and P. Reynolds, "Cultural norms \& business start-ups: the impact of national values on opportunity and necessity entrepreneurs", International Entrepreneurship and Management Journal, vol. 5, no. 4, pp. 417-437, 2009.

[34] L. Thach and R. Kidwell, "HR practices in US and Australian family wineries: cultural contrasts and performance impact", International Entrepreneurship and Management Journal, vol. 5, no. 2, pp. 219-240, 2008.

[35] R. Burke, Women and minorities in science, technology, engineering and mathematics. Cheltenham: E. Elgar, 2007.

[36] S. Ceci, W. Williams and S. Barnett, "Women's underrepresentation in science: Sociocultural and biological considerations.", Psychological Bulletin, vol. 135, no. 2, pp. 218-261, 2009.

[37] S. Ceci and W. Williams, "Understanding current causes of women's underrepresentation in science", Proceedings of the National Academy of Sciences, vol. 108, no. 8, pp. 3157-3162, 2011.

[38] S. Cheryan, S. Ziegler, A. Montoya and L. Jiang, "Why are some STEM fields more gender balanced than others?", Psychological Bulletin, vol. 143, no. 1, pp. 1-35, 2017.

[39] G. Stoet and D. Geary, "The Gender-Equality Paradox in Science, Technology, Engineering, and Mathematics Education", Psychological Science, vol. 29, no. 4, pp. 581-593, 2018.

[40] W. Williams and S. Ceci, "National hiring experiments reveal 2:1 faculty preference for women on STEM tenure track", Proceedings of the National Academy of Sciences, vol. 112, no. 17, pp. 5360-5365, 2015.

[41] V. Gupta, A. Goktan and G. Gunay, "Gender differences in evaluation of new business opportunity: A stereotype threat perspective", Journal of Business Venturing, vol. 29, no. 2, pp. 273-288, 2014.
[42] W. Bönte and M. Piegeler, "Gender gap in latent and nascent entrepreneurship: driven by competitiveness", Small Business Economics, vol. 41, no. 4, pp. 961-987, 2012.

[43] D. Sexton and N. Bowman-Upton, "Female and male entrepreneurs: Psychological characteristics and their role in gender-related discrimination", Journal of Business Venturing, vol. 5, no. 1, pp. 29-36, 1990.

[44] M. Lévesque and M. Minniti, "The effect of aging on entrepreneurial behavior", Journal of Business Venturing, vol. 21, no. 2, pp. 177-194, 2006.

[45] G. Montes Rojas and L. Siga, "On the nature of micro-entrepreneurship: evidence from Argentina", Applied Economics, vol. 41, no. 21, pp. 2667-2680, 2009.

[46] M. Thomas, "The impact of education histories on the decision to become self-employed: a study of young, aspiring, minority business owners", Small Business Economics, vol. 33, no. 4, pp. 455-466, 2009.

[47] D. Blanchflower and B. Meyer, "A longitudinal analysis of the young self-employed in Australia and the United States", Small Business Economics, vol. 6, no. 1, pp. 1-19, 1994.

[48] A. Shapero, "Are business schools teaching business?", Inc, 1980.

[49] J. Fallows, "The case against credentialism", Atlantic Monthly, pp. 4967, 1985.

[50] R. Ronstadt, Entrepreneurship. Dover, Mass.: Lord Pub., 1984.

[51] M. Laukkanen, "Exploring alternative approaches in high-level entrepreneurship education: creating micromechanisms for endogenous regional growth", Entrepreneurship \& Regional Development, vol. 12, no. 1, pp. 25-47, 2000.

[52] N. Peterman and J. Kennedy, "Enterprise Education: Influencing Students' Perceptions of Entrepreneurship", Entrepreneurship Theory and Practice, vol. 28, no. 2, pp. 129-144, 2003.

[53] S. Wu and $\mathrm{L}$. Wu, "The impact of higher education on entrepreneurial intentions of university students in China", Journal of Small Business and Enterprise Development, vol. 15, no. 4, pp. 752-74, 2008.

[54] P. Robinson and E. Sexton, "The effect of education and experience on self-employment success", Journal of Business Venturing, vol. 9, no. 2, pp. 141-156, 1994.

[55] B. Honig and P. Davidsson, "The Role of Social and Human Capital Among Nascent Entrepreneurs.", Academy of Management Proceedings, vol. 2000, no. 1, pp. B1-B6, 2000.

[56] Z. İlhan Ertuna and E. Gurel, "The moderating role of higher education on entrepreneurship", Education + Training, vol. 53, no. 5, pp. 387-402, 2011.

[57] H. Mintzberg, Managers, not MBAs: A hard look at the soft practice of managing and management development. Berrett-Koehler Publishers., 2004.

[58] E. Gurel, L. Altinay and R. Daniele, "Tourism students' entrepreneurial intentions", Annals of Tourism Research, vol. 37, no. 3, pp. 646-669, 2010.

[59] S. Singh, R. Reynolds and S. Muhammad, "A Gender-Based Performance Analysis of Micro and Small Enterprises in Java, Indonesia", Journal of Small Business Management, vol. 39, no. 2, pp. 174-182, 2001.

[60] M. Schippers, A. Scheepers and J. Peterson, "A scalable goal-setting intervention closes both the gender and ethnic minority achievement gap", Palgrave Communications, vol. 1, no. 1, 2015.

[61] B. Hallen, C. Bingham and S. Cohen, "Do Accelerators Accelerate? A Study of Venture Accelerators as a Path to Success?", Academy of Management Proceedings, vol. 2014, no. 1, p. 12955, 2014.

[62] "Turkey - Hofstede Insights", Hofstede Insights, 2019. [Online]. Available: https://www.hofstede-insights.com/country/turkey/ [Accessed: 20- May- 2019]. 